\title{
Time-series responses of swine plasma metabolites to ingestion of diets containing myo-inositol or phytase
}

\author{
Aaron J. Cowieson ${ }^{1 *}$, Franz F. Roos ${ }^{1}$, Jean-Paul Ruckebusch ${ }^{1}$, Jonathan W. Wilson ${ }^{1}$, Patrick Guggenbuhl ${ }^{1}$, \\ Hang $\mathrm{Lu}^{2}$, Kolapo M. Ajuwon ${ }^{2}$ and Olayiwola Adeola ${ }^{2}$ \\ ${ }^{1}$ DSM Nutritional Products, Wurmisweg 576, 4303 Kaiseraugst, Switzerland \\ ${ }^{2}$ Department of Animal Sciences, Purdue University, West Lafayette, IN 47907, USA
}

(Submitted 28 July 2017 - Final revision received 25 September 2017 - Accepted 5 October 2017)

\section{Abstract}

The effect of the ingestion of diets containing either $m y$-inositol or exogenous phytase on plasma metabolites was examined using $29 \mathrm{~kg}$ barrows. The diets were: control (maize, soya, rapeseed, rice bran), control plus $2 \mathrm{~g} / \mathrm{kg} m y o$-inositol, control plus $1000 \mathrm{phytase}$ units (FYT)/kg or $3000 \mathrm{FYT} / \mathrm{kg}$ exogenous phytase. Pigs were housed in a PigTurn device and blood was collected, from jugular catheters, via an automated system at -30, (30 min before feeding), 0, 15, 30, 45, 60, 90, 120, 150, 180, 240, 300 and $360 \mathrm{~min}$ post-feeding. The addition of $2 \mathrm{~g} / \mathrm{kg}$ myo-inositol to the basal diet resulted in an increase in plasma myo-inositol concentration that was evident $45-60$ min after diet introduction and persisted to $360 \mathrm{~min}$ post-feeding. Similarly, supplementation of the basal diet with either 1000 or $3000 \mathrm{FYT} / \mathrm{kg}$ exogenous phytase resulted in an increase in plasma myo-inositol concentration that was still rising 360 min post-feeding. Plasma P concentration was increased over time by the addition of 1000 and $3000 \mathrm{FYT} / \mathrm{kg}$ phytase, but not by the addition of $m y o$-inositol. Other plasma metabolites examined were not affected by dietary treatment. It can be concluded that oral delivery of myo-inositol results in rapid increase in plasma $m y o$-inositol concentrations that peak approximately 45-60 min after feeding. Use of supplemental phytase achieves similar increases in myo-inositol concentration in plasma but the appearance is more gradual. Furthermore, supplementation of pig diets with exogenous phytase results in rapid appearance of $\mathrm{P}$ in plasma that may be sustained over time relative to diets with no added phytase.

\section{Key words: Pigs: Myo-inositol: Phytase: Plasma: Time-series}

Phytic acid (1,2,3,4,5,6 myo-inositol hexakis dihydrogen phosphate) is the principal storage form of phosphate in plant seeds and is found at concentrations of $5-50 \mathrm{~g} / \mathrm{kg}$ in cereals, grain legumes and oilseed meals ${ }^{(1)}$. Phytic acid is strongly electronegative and readily forms chelates with cations such as $\mathrm{Ca}, \mathrm{Zn}$, $\mathrm{Fe}$ and $\mathrm{Cu}^{(2)}$, rendering both phytic acid and the associated mineral(s) poorly soluble and so recalcitrant to digestion. In addition, phytic acid has been shown to increase endogenous amino acid flow in the ileum of broilers ${ }^{(3)}$, putatively via a mechanism involving hyper-secretion of pepsin, mucin, $\mathrm{HCl}$ and $\mathrm{NaHCO}_{3}{ }^{(4)}$. The capacity to form insoluble precipitates with nutritionally-relevant minerals, and the antagonistic effect on $\mathrm{N}$ cycling (through detrimental changes to mucin integrity, endogenous enzyme secretion and amino acid absorption) in the intestine have been nutritional obstacles that have attracted substantial research interest, especially in the area of phytase (the exogenous enzyme responsible for the hydrolysis of phytic acid). However, the relevance of myo-inositol in phytasemediated effects remains largely unexplored. For example, it is not clear how quickly myo-inositol is absorbed, what effect this has on various metabolic indicators and, crucially, whether there are differences in response when myo-inositol is delivered orally compared with indirect genesis through the action of exogenous phytase in the gut.

The beneficial effects of exogenous phytase in the diets of non-ruminants are unequivocal and oriented strongly around improvements in the solubility and digestibility of $\mathrm{P}$ and the consequences of the use of phytase in animal agriculture on improving sustainability has been considerable ${ }^{(5,6)}$. However, although displacement of inorganic $\mathrm{P}$ in the diets of pigs and poultry has been the primary driver of growth in phytase use since its introduction as a commercially relevant feed additive in the early 1990s, more recently, the so-called 'extra-phosphoric' effects have gained importance ${ }^{(7)}$. These 'extra-phosphoric' effects are associated with the strong electro-negative charge carried by phytic acid at intestinal $\mathrm{pH}$ that causes chelation between phytic acid and various divalent cations and also interaction between phytic acid and protein ${ }^{(8,9)}$. In addition to reducing the bioavailability of dietary cations and protein, these interactions influence endogenous protein and mineral losses, and may reduce the integrity of intestinal mucin and influence the electrolyte balance in the lumen ${ }^{(4,10,11)}$. Delivery of these

\footnotetext{
Abbreviations: CD, control diet; FYT, phytase units.
}

* Corresponding author: A. J. Cowieson, email aaron.cowieson@dsm.com 
extra-phosphoric effects, for example digestible energy, amino acids and various minerals, relies on the rapid and complete dephosphorylation of phytic acid (especially the higher esters) in the cephalic gastrointestinal tract ${ }^{(12-14)}$, but are reasonably consistent. This contextual discussion is important because so-called 'superdosing' of phytase putatively improves performance of pigs and poultry at a level that is not readily explained by a log-linear response curve for digestible minerals or amino acids. Realisation of these phytase-mediated effects across various enzyme inclusion concentrations and the apparent disconnect with 'super-dosing' narratives led to an increase in interest in myo-inositol and the potential role of this moiety in phytase responses. Zyla et al. ${ }^{(15)}$ and Cowieson et al. ${ }^{(16)}$ noted positive effects of the oral supply of myo-inositol to broilers (at dietary concentrations similar to that which may be expected to be released by phytase). Cowieson et al. ${ }^{(17)}$ and Guggenbuhl et $a l^{(18)}$ observed that supplementation of a broiler or swine diet with exogenous phytase resulted in a significant increase in myo-inositol in plasma, suggesting that phytase effects may be similar to those of direct addition of myo-inositol to diets. Walk et $a l .{ }^{(19)}$ also noted that the addition of exogenous phytase to the diets of broilers resulted in an increase in the concentration of $m y o$-insotiol in the gizzard and that these effects were correlated with bird performance. However, the absorption of myo-inositol, when fed directly, or myo-inositol, when generated in situ by phytase, is not well understood and how (or if) myo-inositol concentration in plasma is regulated is unclear. The hypothesis of the study presented herein was that addition of $m y o$-inositol to the diet would result in a rapid appearance of the same in plasma and that similar responses would be noted by the addition of an exogenous microbial phytase. Some differences in response of alternative blood parameters to supplementation of diets with either phytase or myo-inositol were anticipated.

\section{Methodology}

All procedures were approved by Purdue University Animal Care and Use Committee.

\section{Pigs and diets}

Barrows (Duroc $\times$ Yorkshire $\times$ Landrace terminal crosses from equal parity sows) with an average initial body weight 28.7 (SD 1.0$) \mathrm{kg}$, fitted with indwelling jugular catheters, were used in this study. Pigs received a daily allowance of the basal diet at $11.6 \%$ of the metabolic BW of the lightest pig before experiment started at 08.30 and 14.30 with free access to water. Barrows were randomly assigned to four diets, on the day they were moved into the PigTurn (BASi) based on their body weights. The four diets were: (1) control diet (CD) that was formulated to meet nutrient requirements of $20-30 \mathrm{~kg}$ pigs; (2) $\mathrm{CD}+2 \mathrm{~g}$ myo-inositol/kg; (3) $\mathrm{CD}+$ phytase at 1000 phytase units $(\mathrm{FYT}) / \mathrm{kg}$; (4) $\mathrm{CD}+$ phytase at $3000 \mathrm{FYT} / \mathrm{kg}$ (Table 1). The experimental diets were offered, to eight pigs per diet, only on the day blood samples were collected. Prior to introduction of the experimental diets all pigs received the CD. At time 0 (08.30 hours), pigs were offered half of the total daily
Table 1. Ingredient composition of experimental diets on an as-fed (unless otherwise indicated) basis

\begin{tabular}{|c|c|c|c|c|}
\hline \multirow[b]{2}{*}{ Ingredients } & \multicolumn{4}{|c|}{ Dietary treatment } \\
\hline & CD & CD + Inositol & $\begin{array}{l}\text { CD + } 1000 \\
\text { Phytase }\end{array}$ & $\begin{array}{c}C D+3000 \\
\text { Phytase }\end{array}$ \\
\hline Maize & $450 \cdot 55$ & $430 \cdot 55$ & 440.55 & 420.55 \\
\hline Rapeseed meal & 200 & 200 & 200 & 200 \\
\hline Rice bran & 200 & 200 & 200 & 200 \\
\hline Soyabean meal & 100 & 100 & 100 & 100 \\
\hline Limestone & $12 \cdot 8$ & $12 \cdot 8$ & $12 \cdot 8$ & $12 \cdot 8$ \\
\hline Salt & 3.5 & 3.5 & 3.5 & 3.5 \\
\hline Soyabean oil & 23 & 23 & 23 & 23 \\
\hline Lys-HCl & $5 \cdot 2$ & $5 \cdot 2$ & $5 \cdot 2$ & $5 \cdot 2$ \\
\hline DL-Met & 0.4 & 0.4 & 0.4 & 0.4 \\
\hline L-Thr & $1 \cdot 2$ & $1 \cdot 2$ & $1 \cdot 2$ & $1 \cdot 2$ \\
\hline L-Tryp & 0.45 & 0.45 & 0.45 & 0.45 \\
\hline $\begin{array}{l}\text { Swine vitamin } \\
\text { premix }^{*}\end{array}$ & 1.5 & 1.5 & 1.5 & 1.5 \\
\hline Swine TM premix† & 0.9 & 0.9 & 0.9 & 0.9 \\
\hline $\begin{array}{l}\text { Selenium } 270 \\
\text { premix } \neq\end{array}$ & 0.5 & 0.5 & 0.5 & 0.5 \\
\hline Inositol premix§ & 0 & 20 & 0.00 & 0.00 \\
\hline Phytase premixll & 0 & 0 & $10 \cdot 00$ & $30 \cdot 00$ \\
\hline Total & 1000 & 1000 & 1000 & 1000 \\
\hline \multicolumn{5}{|c|}{ Analysed nutrient composition } \\
\hline $\mathrm{GE}(\mathrm{MJ} / \mathrm{kg})$ & $17 \cdot 59$ & $17 \cdot 61$ & $17 \cdot 48$ & $17 \cdot 47$ \\
\hline $\mathrm{CP}(\mathrm{g} / \mathrm{kg})$ & 189 & 188 & 192 & 193 \\
\hline $\mathrm{Ca}(\mathrm{g} / \mathrm{kg})$ & 11.9 & 11.4 & $12 \cdot 2$ & 11.9 \\
\hline$P(g / k g)$ & $7 \cdot 3$ & $7 \cdot 6$ & $7 \cdot 3$ & $7 \cdot 9$ \\
\hline Inositol (g/kg) & 0.3 & $2 \cdot 4$ & 0.3 & 0.3 \\
\hline Total InPsף (g/kg DM) & $6 \cdot 44$ & $6 \cdot 22$ & $6 \cdot 26$ & $6 \cdot 23$ \\
\hline Phytase (FYT/kg) & 80 & 72 & 996 & 3204 \\
\hline
\end{tabular}

$\mathrm{CD}$, control diet; GE, gross energy; FYT, phytase units.

* Supplied the following per kg of diet: vitamin $A, 1089 \mu \mathrm{g}$; vitamin $D_{3}, 9.1 \mu \mathrm{g}$; vitamin $\mathrm{E}, 23.7 \mathrm{mg}$; menadione, $1.32 \mathrm{mg}$; riboflavin, $5.28 \mathrm{mg}$; D-pantothenic acid, $13.1 \mathrm{mg}$; niacin, $19.8 \mathrm{mg}$; choline chloride, $771 \mathrm{mg}$; vitamin $\mathrm{B}_{12}, 23.1 \mathrm{ug}$.

† Supplied the following per kg of diet: iodine, $0.46 \mathrm{mg} ; \mathrm{Mn}, 15 \mathrm{mg} ; \mathrm{Cu}, 11.3 \mathrm{mg} ; \mathrm{Fe}$, $121.3 \mathrm{mg} ; \mathrm{Zn}, 121.2 \mathrm{mg}$.

‡ Selenium premix provided $0.3 \mathrm{mg} \mathrm{Se} / \mathrm{kg}$ diet.

$\S$ Inositol premix made to $0.1 \mathrm{~g} / \mathrm{kg}$ which when added at $20 \mathrm{~g} / \mathrm{kg}$ provided $2 \mathrm{~g}$ inositol/ $\mathrm{kg}$ diet.

II Phytase premix (RONOZYME HiPhos; DSM Nutritional Products) made to $0.01 \mathrm{~g} / \mathrm{kg}$ which when added at 10 or $30 \mathrm{~g} / \mathrm{kg}$ provided $0.1 \mathrm{~g} / \mathrm{kg}$ or $0.3 \mathrm{~g} / \mathrm{kg}$ diet $(1000$ or $3000 \mathrm{FYT} / \mathrm{kg}$, respectively).

I Total phytate-bound P.

feed allowance, and simultaneously bled for the time 0 bleeding (the -30 bleeding was at 08.00 hours). A period of 15 min later, which is $15 \mathrm{~min}$ after feeding, they were bled again. And then bled 30, 45, 60, 90, 120, 150, 180, 240, 300 and 360 min after feeding. After the last bleeding (16.30 hours), they were fed the second installment of the total daily feed allocation. They were not bled again after the second feeding. The process was repeated eight times for each treatment because there were only four PigTurn devices, so only one replicate per treatment could be handled consecutively.

\section{PigTurn blood collection device}

The PigTurn consisted of a $1 \cdot 2-\mathrm{m}$ diameter animal enclosure in an octagonal shape giving $1.12 \mathrm{~m}^{2}$ floor area (see Fig. 1). The floor was plastic-coated perforated steel and the side walls were solid, clear plastic with aluminum supports. A drive system consisting of an electric motor with gear reduction, a belt drive, and an adjustable speed motor controller allowed external 


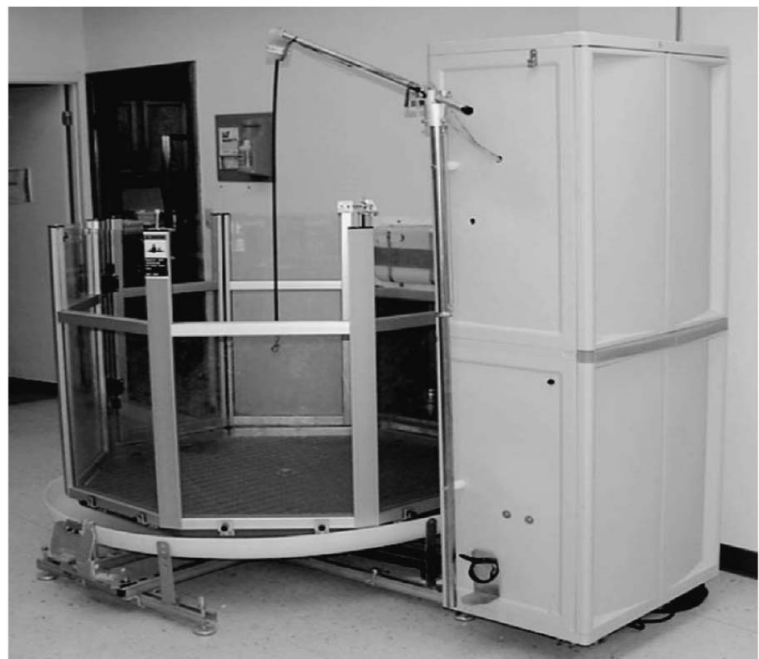

Fig. 1. Digital photograph of the PigTurn.

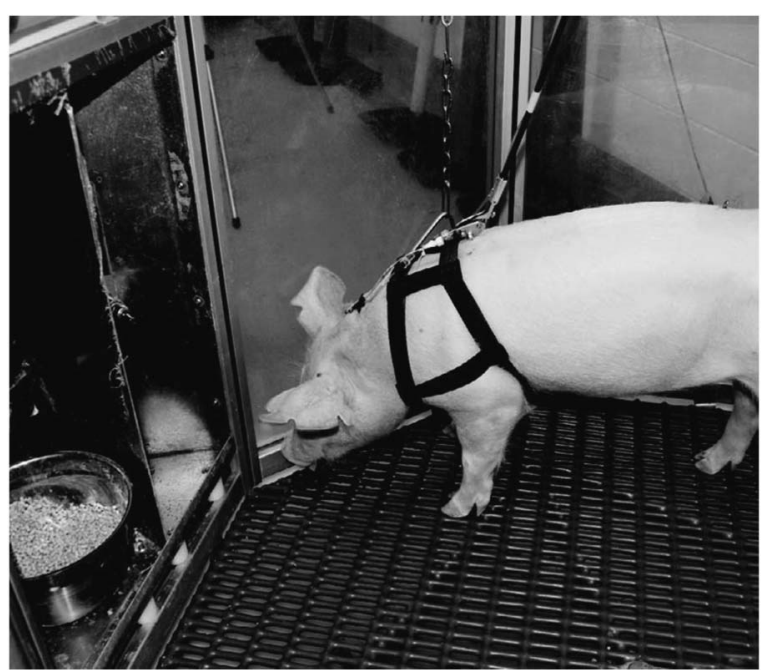

Fig. 2. Digital photograph of a pig in the PigTurn.

control of clockwise and counterclockwise rotation of the enclosure. The feedback control of the drive system consisted of a tether connecting the pig via a harness (see Fig. 2) to an optical sensor array suspended above the enclosure. The sensor array converted the pig movement outside an allowed $270^{\circ}$ arc into a signal that triggered the drive system to rotate the enclosure in the opposite direction of the pig movement. This allowed the pig to remain relatively constant in relation to the room while allowing movement in the pen. This system also enabled automatic recording of time, direction and duration of animal movement. The harness was an adjustable $\mathrm{H}$-design with additional strapping to control movement or slippage while on the pig.

\section{Surgery}

Surgical placement of jugular catheter and housing in the PigTurn were as described by Marchant-Forde et al. ${ }^{(20)}$. In brief, feed was withdrawn $12 \mathrm{~h}$ before planned surgery and anaesthesia was induced by intramuscular injection of $2.2 \mathrm{mg} / \mathrm{kg}$ of a mixture of $50 \mathrm{mg} / \mathrm{ml}$ each of tiletamine, zolazepam (combined as Telazol; Fort Dodge Animal Health), ketamine (Ketaset; Fort Dodge Animal Health) and xylazine (Sedazine; Fort Dodge Animal Health). The external jugular vein was isolated and two loose ligatures of 2-0 non-absorbable suture (Ethilon; Ethicon Inc.) were placed. A trocar was passed from the dorsal site to the ventral cervical incision as an assistant protected the vessels. The trocar was withdrawn as the surgeon set the 7-french, double-lumen, central venous catheter (Arrow International) into the dorsal incision. An H-harness was fitted to the pig and the catheter end was attached to the harness using a zip-tie. The catheter was blocked with a heparin lock and the pig was given intramuscular injection of analgesic (flunixin meglumine; Banamine-Merck Animal Health) at $2.2 \mathrm{mg} / \mathrm{kg}$ and antibiotic (Cefazolin) at $50 \mathrm{mg} / \mathrm{kg}$. The pig was then transported to a slatted floor pen for recovery after voluntary movement was evident. All surgeries for each pig took approximately $45 \mathrm{~min}$.

\section{Blood collection}

Pigs were moved to the PigTurn $24 \mathrm{~h}$ post-surgery, the harness was hooked up to the tether, and the pen rotation system was activated (Fig. 1 and 2). The catheter was attached to a 2-m catheter extension fixed to the automatic sampling system (Culex-L; BASi), which was programmed to collect blood at the collection intervals: -30 , (30 min before feeding), 0, 15, 30, 45, $60,90,120,150,180,240,300$ and 360 min post-feeding. Feed and water were provided ad libitum. Heparinised saline was used to maintain catheter patency. Blood was collected into heparinised tubes. Catheter lines were flushed with heparinised saline in between collections to prevent coagulation and line blockage. Blood was held at $4^{\circ} \mathrm{C}$ for $7 \mathrm{~h}$ before being centrifuged at $2000 \mathrm{~g}$ at $4^{\circ} \mathrm{C}$ for $10 \mathrm{~min}$ to separate the plasma and then aliquoted into $1 \cdot 5-\mathrm{ml}$ centrifuge tubes and stored at $-80^{\circ} \mathrm{C}$ until subsequent analyses.

\section{Chemical analyses}

Plasma myo-inositol samples were prepared in duplicate as described by Frieler et $a l .{ }^{(21)}$ and analysed by ultra-performance liquid chromatography/MS according to the method of Leung et $a l .{ }^{(22)}$. P, Ca, alkaline phosphatase (ALP), glucose, TAG and urea in plasma were determined in duplicate with a biomedical automate Cobas 6000 (Roche Diagnostics).

In-feed phytase activity was determined by Biopract $\mathrm{GmbH}$. One FYT of phytase (EC 3.1.3.2) is defined as the quantity of enzyme which sets free $1 \mu \mathrm{mol}$ of inorganic phosphate/min from $5.0 \mu \mathrm{mol} / 1$ sodium phytate at $\mathrm{pH} 5.5$ and at $37^{\circ} \mathrm{C}$.

\section{Statistical analysis}

All statistical analyses were performed in the statistical software R, version 3.2.2 (2015; R Core Team), running on Windows 7. Statistical differences at time 0 were tested by ANOVA followed by a Tukey's post hoc test. For the ANCOVA analyses, the outcome at $360 \mathrm{~min}$ was predicted using the dietary treatment 
as the main factor and the baseline level at $0 \mathrm{~min}$ as covariate, to adjust for initial (immediately prior to receiving the experimental diets) differences among individual animals. The intermediate time points between 0 and 360 min were not included. A Tukey's post hoc test was applied after the ANCOVA. For the linear regression model over time, a mixed model was applied using the function lme $\mathrm{O}$ in the library nlme. All time points from 0 to $360 \mathrm{~min}$ were included in this model, to increase statistical power. Time, dietary treatment and their interaction were included as fixed factors, and the individual animal was included as a random factor, which adjusted for initial differences. The gradual divergence between the dietary treatments over time, that is the difference among their slopes, was clearly reflected in the time-treatment interaction coefficients, as expected for such a response pattern. The dietary treatment term by itself did not contribute significant effects as the treatment groups did not yet differ at baseline. As baseline differences were also captured in the random effect of the individual animal, the dietary treatment term by itself was ultimately omitted in the final analyses. For the dose-response regression, the myo-inositol group was excluded and the dose was coded as 0,1000 and $3000 \mathrm{FYT} / \mathrm{kg}$, resulting in a single coefficient for this continuous dose variable. In the dose-response regression, the continuous dose variable was kept as a predictor in the model as that was just a single coefficient. The regression analyses were not adjusted post hoc.

\section{Results}

Plasma metabolite concentrations across the four dietary treatments at time zero are presented in Table 2 and after $360 \mathrm{~min}$ of feeding are presented in Table 3. No significant differences among treatment groups were observed at time 0 , but the values at time 0 were included as a covariate or random factor in the statistical models nevertheless to adjust for any initial differences among individuals. However, $360 \mathrm{~min}$ after receiving the experimental diets there was an increase (ANCOVA, $P<0.05$ each) in plasma myo-inositol for pigs that were fed the diets containing either myo-inositol or phytase compared $v$. control. In a linear mixed model regression over time, the concentration in the 1000 and $3000 \mathrm{FYT} / \mathrm{kg}$ groups gradually increased $v$. the control group $(P<0 \cdot 001$ each). Including the intermediated time points in the regression model seemed to enhance the statistical power. When dose was coded as a continuous variable, there was a linear $(P<0.001)$ effect of phytase dose, that is plasma myo-inositol concentration was positively correlated with phytase dose. The concentration in the $3000 \mathrm{FYT} / \mathrm{kg}$ group increased more than the $1000 \mathrm{FYT} / \mathrm{kg}$ group (regression, $P=0.026$, unadjusted), in line with that correlation. There were no effects of diet on plasma ALP, Ca, glucose, TAG or urea. However, plasma P concentration at $360 \mathrm{~min}$ was increased $v$. control (ANCOVA, $P<0.001$; regression over time, $P<0 \cdot 001$; Fig. 4) by the addition

Table 2. Plasma metabolites from pigs $(n$ ) fed a control diet, myo-inositol or phytase (1000 or 3000 phytase units $(\mathrm{FYT}) / \mathrm{kg})$ at time $0(0 \mathrm{~min})$ (Mean values and standard deviations)

\begin{tabular}{|c|c|c|c|c|c|c|c|c|c|c|}
\hline \multirow[b]{3}{*}{ Metabolites } & \multicolumn{8}{|c|}{ Dietary treatment } & & \\
\hline & \multicolumn{2}{|c|}{ Control } & \multicolumn{2}{|c|}{ Myo-inositol } & \multicolumn{2}{|c|}{$1000 \mathrm{FYT} / \mathrm{kg}$} & \multicolumn{2}{|c|}{$3000 \mathrm{FYT} / \mathrm{kg}$} & \multicolumn{2}{|r|}{ Probability } \\
\hline & Mean & SD & Mean & SD & Mean & SD & Mean & SD & $P<$ & Linear phytase $(P<)$ \\
\hline Myo-inositol $(\mu \mathrm{mol} / \mathrm{l})$ & $20 \cdot 7$ & 4.5 & $20 \cdot 5$ & $7 \cdot 2$ & $20 \cdot 3$ & $5 \cdot 1$ & $23 \cdot 4$ & 4.6 & NS & NS \\
\hline $\mathrm{P}(\mathrm{mg} / 100 \mathrm{ml})$ & $5 \cdot 2$ & 0.8 & 5.5 & 0.4 & $5 \cdot 8$ & 0.7 & 5.4 & 0.8 & NS & NS \\
\hline ALP $(U / I)$ & $136 \cdot 6$ & $36 \cdot 3$ & $136 \cdot 9$ & $35 \cdot 8$ & $122 \cdot 6$ & 37.3 & 118.6 & $32 \cdot 7$ & NS & NS \\
\hline $\mathrm{Ca}(\mathrm{mg} / 100 \mathrm{ml})$ & $8 \cdot 4$ & 0.7 & $9 \cdot 0$ & 0.7 & 8.8 & 0.6 & $8 \cdot 7$ & 0.6 & NS & NS \\
\hline Glucose $(\mathrm{mg} / 100 \mathrm{ml})$ & 74.4 & 13.5 & $77 \cdot 1$ & $15 \cdot 9$ & 74.3 & 8.7 & $80 \cdot 3$ & 15.4 & NS & NS \\
\hline TAG (mg/100 ml) & $18 \cdot 0$ & $6 \cdot 9$ & $18 \cdot 7$ & 4.7 & $18 \cdot 7$ & 7.9 & $16 \cdot 8$ & $6 \cdot 5$ & NS & NS \\
\hline Urea (mg/100 ml) & $12 \cdot 4$ & 3.0 & 11.3 & 3.3 & $12 \cdot 8$ & 3.6 & 13.5 & 2.5 & NS & NS \\
\hline
\end{tabular}

ALP, alkaline phosphatase.

Table 3. Plasma metabolites from pigs ( $n$ 8) fed a control diet, myo-inositol or phytase (1000 or 3000 phytase units $(\mathrm{FYT}) / \mathrm{kg}$ ) after $360 \mathrm{~min}$ (Mean values and standard deviations)

\begin{tabular}{|c|c|c|c|c|c|c|c|c|c|c|}
\hline \multirow[b]{3}{*}{ Metabolites } & \multicolumn{8}{|c|}{ Dietary treatment } & & \\
\hline & \multicolumn{2}{|c|}{ Control } & \multicolumn{2}{|c|}{ Myo-inositol } & \multicolumn{2}{|c|}{$1000 \mathrm{FYT} / \mathrm{kg}$} & \multicolumn{2}{|c|}{$3000 \mathrm{FYT} / \mathrm{kg}$} & \multicolumn{2}{|r|}{ Probability } \\
\hline & Mean & SD & Mean & SD & Mean & SD & Mean & SD & $P<$ & Linear phytase $(P<)$ \\
\hline Myo-inositol $(\mu \mathrm{mol} / \mathrm{l})$ & $24 \cdot 0^{a}$ & $6 \cdot 6$ & $40 \cdot 7^{\mathrm{b}}$ & $18 \cdot 2$ & $37.5^{\mathrm{b}}$ & $9 \cdot 7$ & $47 \cdot 2^{b}$ & $13 \cdot 6$ & 0.01 & 0.001 \\
\hline $\mathrm{P}(\mathrm{mg} / 100 \mathrm{ml})$ & $3 \cdot 6^{\mathrm{a}}$ & 0.5 & $3.9^{\mathrm{a}}$ & 0.5 & $6 \cdot 5^{\mathrm{b}}$ & 0.9 & $7 \cdot 6^{\mathrm{C}}$ & 0.7 & 0.01 & 0.001 \\
\hline $\operatorname{ALP}(\mathrm{U} / \mathrm{l})$ & $142 \cdot 2$ & $30 \cdot 7$ & $141 \cdot 7$ & $35 \cdot 7$ & $137 \cdot 2$ & 48.0 & $131 \cdot 2$ & 39.4 & NS & NS \\
\hline $\mathrm{Ca}(\mathrm{mg} / 100 \mathrm{ml})$ & $8 \cdot 8$ & 1.1 & $9 \cdot 2$ & 0.9 & 9.4 & $1 \cdot 1$ & 8.8 & 0.5 & NS & NS \\
\hline Glucose $(\mathrm{mg} / 100 \mathrm{ml})$ & 82.5 & $12 \cdot 6$ & $86 \cdot 2$ & 11.9 & 89.7 & 13.4 & $86 \cdot 2$ & 9.3 & NS & NS \\
\hline TAG (mg/100 ml) & $22 \cdot 1$ & 8.5 & $22 \cdot 2$ & $7 \cdot 4$ & $22 \cdot 2$ & $7 \cdot 0$ & $23 \cdot 2$ & 4.8 & NS & NS \\
\hline Urea (mg/100 ml) & $15 \cdot 7$ & 5.4 & $16 \cdot 5$ & 3.6 & 18.9 & 4.4 & $16 \cdot 9$ & 1.6 & NS & NS \\
\hline
\end{tabular}

ALP, alkaline phosphatase.

${ }_{a, b, c}$ Mean values in columns with unlike superscript letters were significantly different at the level indicated in the probability column. 
of both 1000 and $3000 \mathrm{FYT} / \mathrm{kg}$ phytase, but not by addition of myo-inositol, which was not significantly different from control. When dose was coded as a continuous variable in the regression, there was a linear $(P<0.001)$ effect of phytase dose, that is plasma $\mathrm{P}$ concentration was positively correlated with phytase dose. The addition of $3000 \mathrm{FYT} / \mathrm{kg}$ increased $\mathrm{P}$ concentration more than the addition of $1000 \mathrm{FYT} / \mathrm{kg}$ (ANCOVA, $P=0.012$; regression over time, $P<0 \cdot 001$ ). Figs 3-9 present the effects of the various dietary interventions on plasma metabolites in pigs from $30 \mathrm{~min}$ before feeding to $360 \mathrm{~min}$

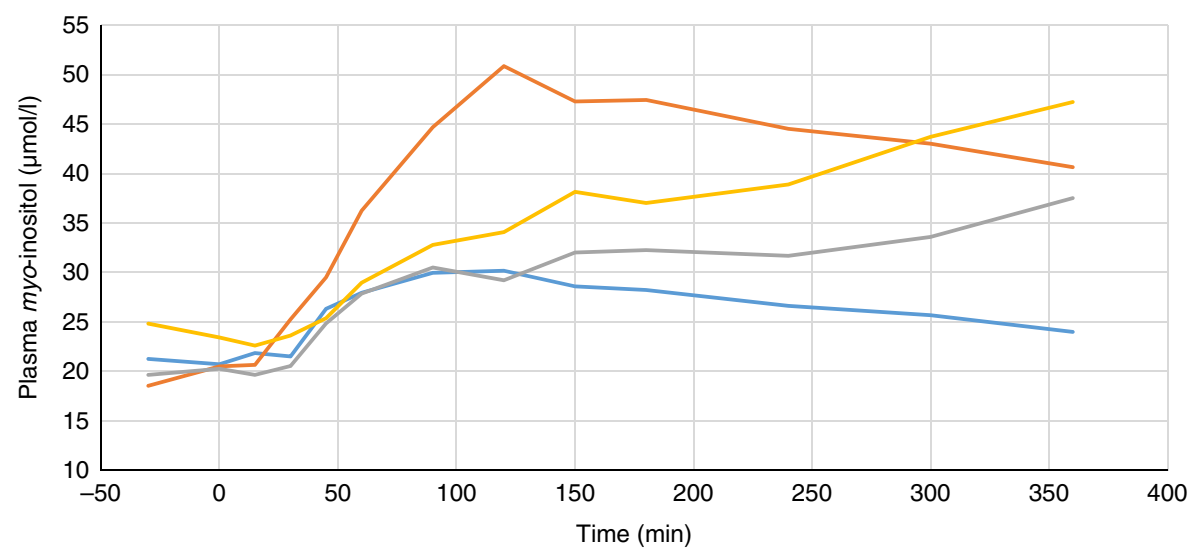

Fig. 3. Effect of feeding myo-inositol or phytase (1000 or 3000 phytase units $(\mathrm{FYT}) / \mathrm{kg})$ on plasma myo-inositol concentration in pigs $(n 8)$. — myo-inositol; , $3000 \mathrm{FYT} / \mathrm{kg}$. All three dietary treatments were higher than control at $360 \mathrm{~min}$ (ANCOVA, $P<0.05$ each)

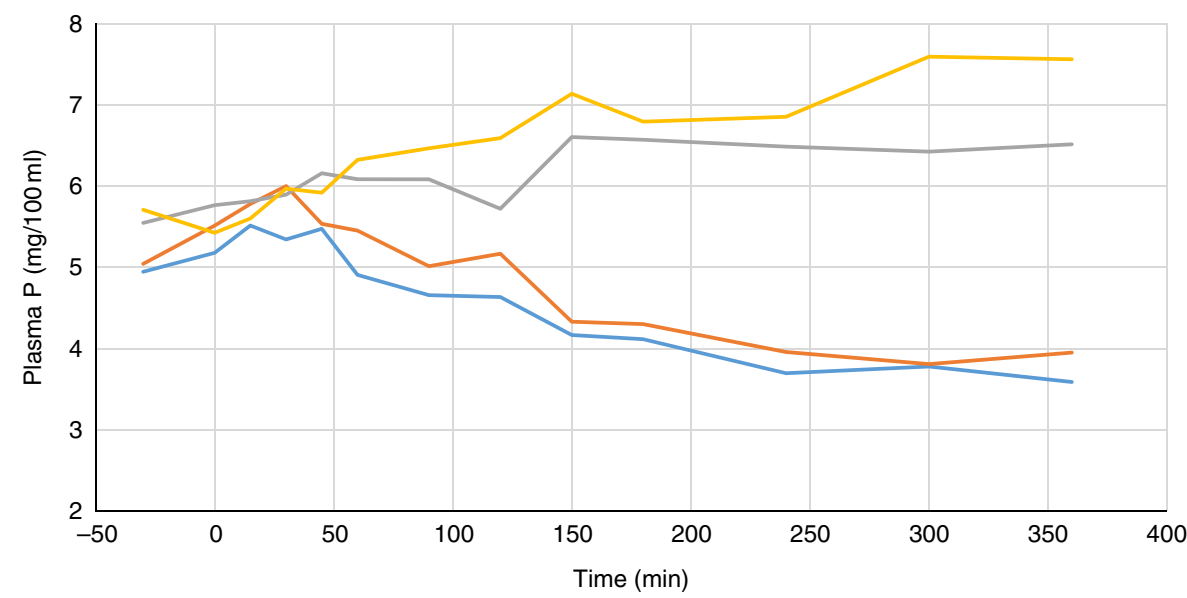

Fig. 4. Effect of feeding myo-inositol or phytase (1000 or 3000 phytase units $(\mathrm{FYT}) / \mathrm{kg})$ on plasma phosphorus concentration $(\mathrm{mg} / 100 \mathrm{ml})$ in pigs $(n)$ ). , myo-inositol; 1000 FYT/Ka; $3000 \mathrm{FYT} / \mathrm{kg}$. The concentrations in the 1000 and $3000 \mathrm{FYT} / \mathrm{kg}$ were higher at $360 \mathrm{~min}$ than those in the control group and the myo-inositol group (ANCOVA, $P<0.001$ for each comparison).

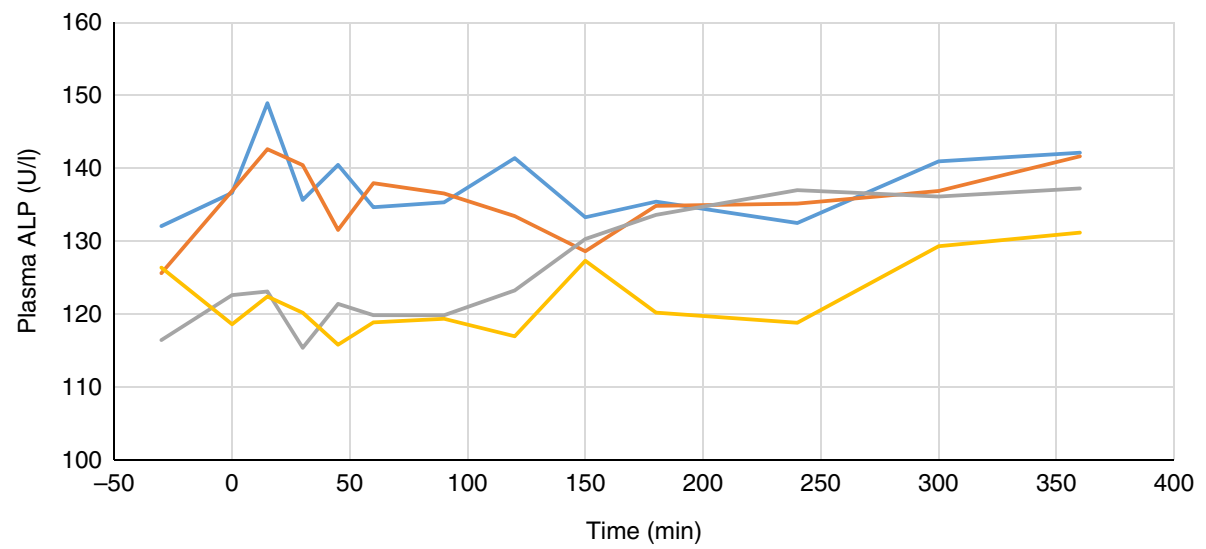

Fig. 5. Effect of feeding myo-inositol or phytase (1000 or 3000 phytase units (FYT)/kg) on plasma alkaline phosphatase (ALP) activity in pigs $(n 8)$. - , Control; myo-inositol; 


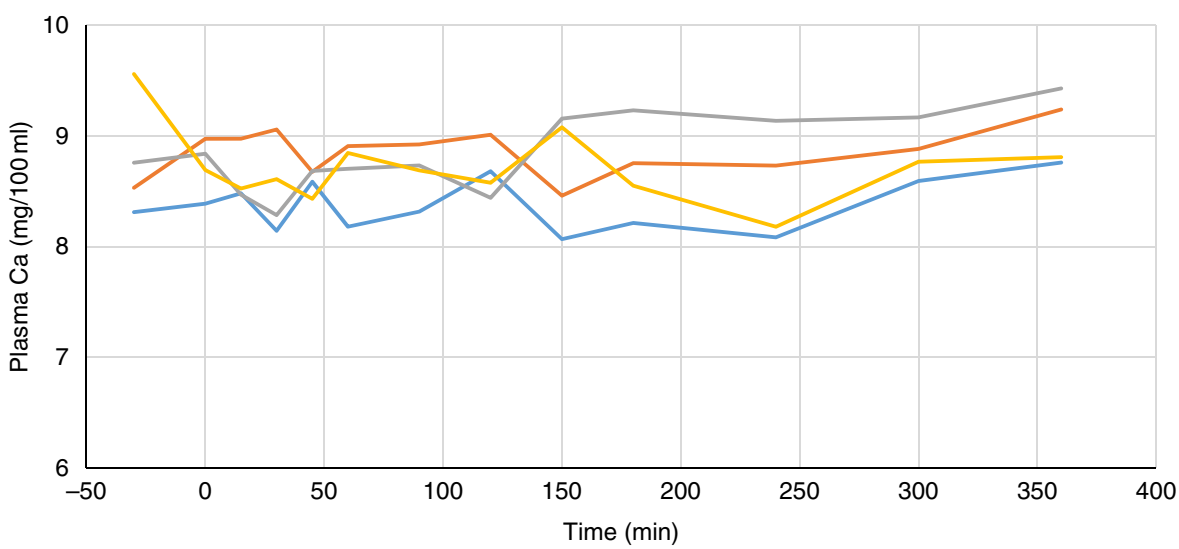

Fig. 6. Effect of feeding myo-inositol or phytase (1000 or 3000 phytase units (FYT)/kg) on plasma calcium concentration (mg/100 ml) in pigs $(n 8)$. - Control; myo-inositol; $1000 \mathrm{FYT} / \mathrm{kg}$ $3000 \mathrm{FYT} / \mathrm{kg}$. No differences among any groups were observed at $360 \mathrm{~min}$ (ANCOVA, $P>0.05$ ).

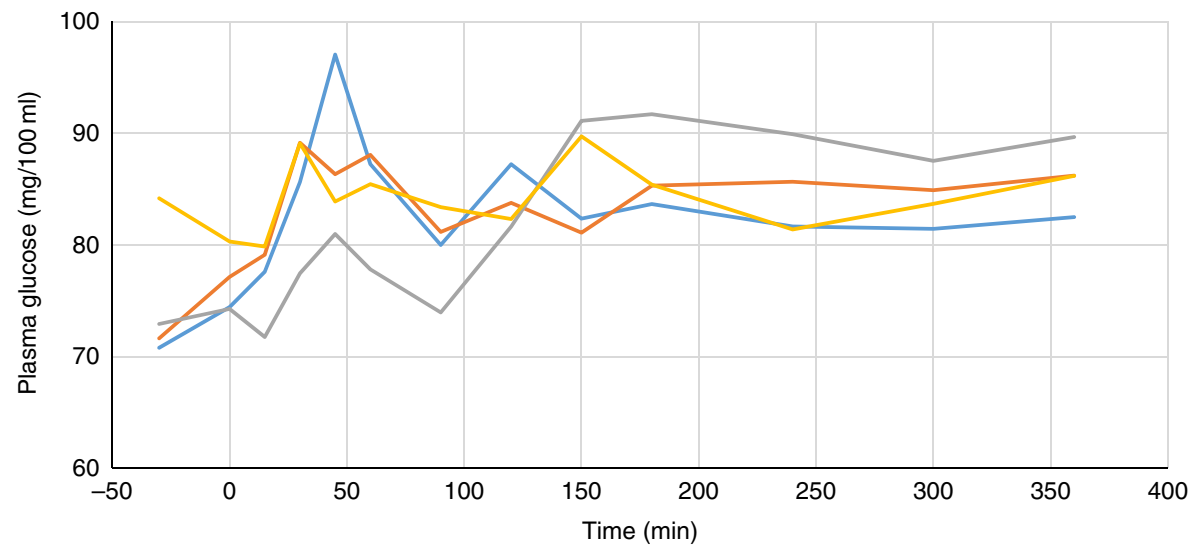

Fig. 7. Effect of feeding myo-inositol or phytase (1000 or 3000 phytase units (FYT)/kg) on plasma glucose concentration (mg/100 ml) in pigs $(n 8)$. — Control; myo-inositol; $1000 \mathrm{FYT} / \mathrm{kg}$

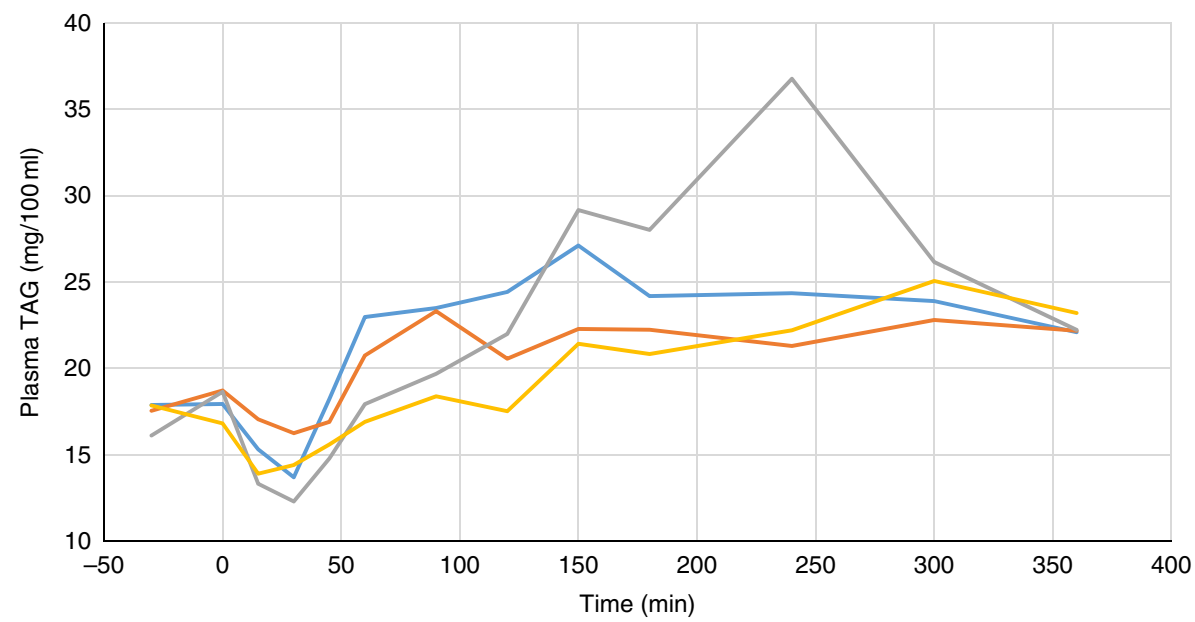

Fig. 8. Effect of feeding myo-inositol or phytase (1000 or 3000 phytase units (FYT)/kg) on plasma TAG concentration (mg/100 ml) in pigs $(n 8)$ myo-inositol; , $1000 \mathrm{FYT} / \mathrm{kg}$ ,$- 3000 \mathrm{FYT} / \mathrm{kg}$. No differences among any groups were observed at $360 \mathrm{~min}$ (ANCOVA, $P>0.05$ ).

after feeding $(-30,0,15,30,45,60,90,120,150,180,240,300$ and $360 \mathrm{~min})$. There was a significant effect of time on plasma myo-inositol concentration for diets containing myo-inositol or either 1000 or $3000 \mathrm{FYT} / \mathrm{kg}$ phytase, but not for the control group, that is elapsed time had no effect on myo-inositol concentration in the animals that received the control diet. Urea concentration increased over time (regression over time, $P<0 \cdot 01$ ), but without significant differences among dietary treatments. There was no effect of time on plasma ALP, Ca, glucose, TAG (Fig. 9). 


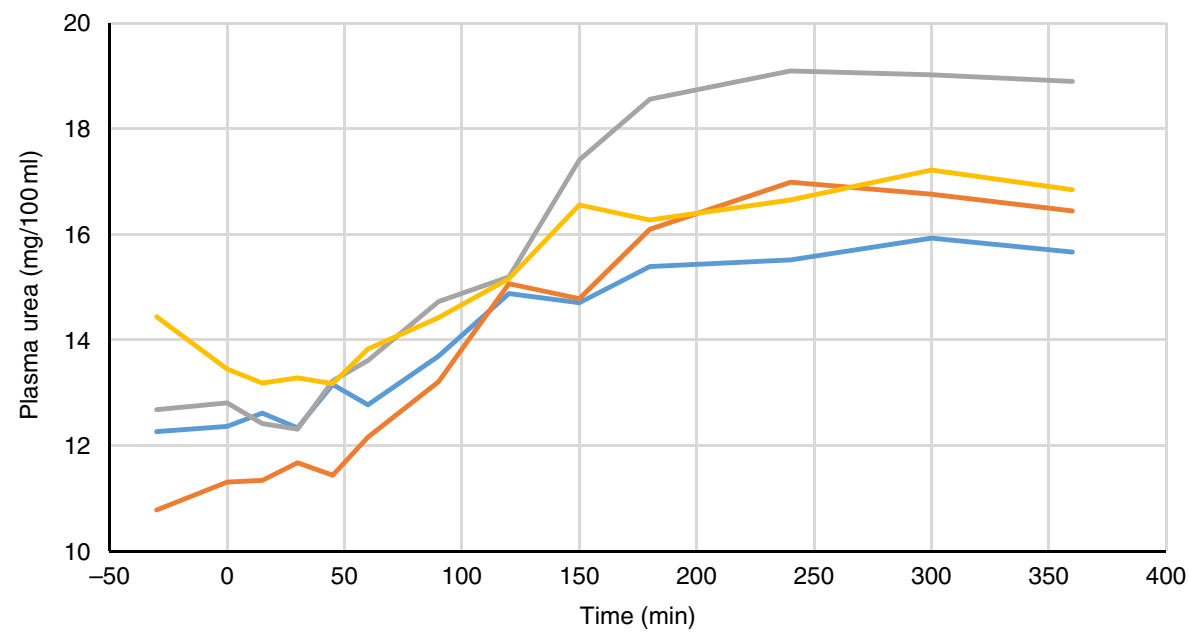

Fig. 9. Effect of feeding myo-inositol or phytase $(1000$ or $3000 \mathrm{FYT} / \mathrm{kg})$ on plasma urea concentration $(\mathrm{mg} / 100 \mathrm{ml})$ in pigs $(n 8)$. —, Control; - , myo-inositol; , $1000 \mathrm{FYT} / \mathrm{kg} ;-3000 \mathrm{FYT} / \mathrm{kg}$. Although urea concentration increased over time $(P<0.01)$, no differences among any groups were observed at $360 \mathrm{~min}$ (ANCOVA and regression, $P>0.05$ ).

\section{Discussion}

Results presented herein show clear and significant responses to plasma myo-inositol when myo-inositol is fed directly or if exogenous phytase is added to the diet. The net result (after $360 \mathrm{~min}$ of feeding) on plasma myo-inositol concentration was similar for the oral supply of $m y o$-inositol or exogenous phytase (either 1000 or $3000 \mathrm{FYT} / \mathrm{kg}$ ). However, the rate of appearance of $m y o-$ inositol in plasma was greater when myo-inositol was added directly to the diet compared with exogenous phytase. For example, $120 \mathrm{~min}$ post-feeding, plasma myo-inositol concentration was significantly higher in the pigs that received myo-inositol than in pigs that received phytase. This suggests that exogenous phytase generates a slow release of myo-inositol that accumulates more slowly in plasma than is the case for a dietary supply of myo-inositol. Whether this influences the biological response to myo-inositol is not clear. However, data presented herein imply a regulation of plasma myo-inositol (increasing till approximately 120 min after feeding and a subsequent decrease), perhaps via insulin-like mechanisms. Myo-inositol is rapidly metabolised into glucuronate by myo-inositol oxygenase (EC 1.13.99.1) in the kidneys followed by urinary excretion ${ }^{(23)}$. Thus, the concentration of myo-inositol is expected to fall following initial peak concentration due to this excretion. The time frame for the maximal peak of serum myo-inositol concentration observed in this study $(120 \mathrm{~min})$ is similar to the range of 90180 min observed in humans who were orally administered myoinositol $^{(24)}$. Furthermore, $m y o$-inositol has recently been found to be an insulin mimetic ${ }^{(25)}$, stimulating the translocation of GLUT4 (the primary insulin-sensitive GLUT in mammals) to the plasma membrane ${ }^{(25,26)}$. Thus, myo-inositol may have 'pronutrient' effects or have involvement in aspects of gluconeogenesis or protein accretion, with obvious implications for animal agriculture. Indeed, effects of phytase and myo-inositol on pathways downstream of IGF-1, for example phosphatidylinositol-3-kinase have recently been reported in poultry ${ }^{(27)}$.

It is possible that the slower release of myo-inositol generated by phytase results in a less acute insulin-like response and may allow a higher plasma concentration to be sustained. This hypothesis requires further elucidation and may require sampling for a longer duration (up to $6-8 \mathrm{~h}$ or more). Nonetheless, the addition of $1000 \mathrm{FYT} / \mathrm{kg}$ and particularly $3000 \mathrm{FYT} / \mathrm{kg}$ of phytase resulted in plasma myo-inositol concentrations similar to that achieved by addition of $2 \mathrm{~g} / \mathrm{kg}$ myo-inositol directly to the diet. As phytic acid contains approximately $30 \%$ myo-inositol $^{(26)}$, this equates to the complete dephosphorylation of about $6 \mathrm{~g} / \mathrm{kg}$ phytic acid to myo-inositol and free phosphate within $4 \mathrm{~h}$ after introduction of phytase.

Most of the measured plasma metabolites in the present experiment were not influenced by dietary treatment and did not vary significantly over time. The lack of effect of phytase and myo-inositol on plasma glucose and TAG is in agreement with previous observations ${ }^{(15,16)}$. However, plasma P concentrations were increased by the supplementation of the diet with both 1000 and $3000 \mathrm{FYT} / \mathrm{kg}$ phytase and this increase was sustained over the duration of the sampling process compared with the control diet or the diet supplemented with myo-inositol (Table 3, Fig. 6). The change in plasma $\mathrm{P}$ associated with phytase is perhaps a little unexpected given the close regulation of plasma $\mathrm{P}$ by the parathyroid hormone and associated mechanisms ${ }^{(28)}$. However, it is possible that these homoeostatic mechanisms take longer than $6 \mathrm{~h}$ to establish equilibrium given the complex interplay between vitamin $\mathrm{D}$, plasma $\mathrm{Ca}$ and $\mathrm{P}$, skeletal $\mathrm{P}$ and $\mathrm{Ca}$, etc., and so a longer duration of sampling may be required to identify whether these phytase-mediated effects on plasma $\mathrm{P}$ are of long-term significance. The lack of response of plasma Ca concentration is also notable and it may be that plasma $\mathrm{Ca}$ is more tightly regulated than plasma $\mathrm{P}$ given that phytase effects on $\mathrm{Ca}$ absorption are consistent and significant $^{(8)}$.

It is concluded that the oral delivery of myo-inositol or phytase supplementation are effective at increasing plasma myoinositol concentrations in pigs. Direct addition of $m y o$-inositol to the diet results in a more rapid appearance of myo-inositol in plasma and this may be regulated via homoeostatic 
mechanisms, putatively involving insulin-like mechanisms $^{(15,16,27)}$. Exogenous phytase addition at either 1000 or $3000 \mathrm{FYT} / \mathrm{kg}$ results in similar plasma myo-inositol concentration changes in plasma to the addition of $2 \mathrm{~g} / \mathrm{kg} m y o$-inositol although the rate of appearance of myo-inositol (and perhaps regulatory responses) is slower. Plasma $\mathrm{P}$ concentration is plastic, at least in the short-term (within $6 \mathrm{~h}$ post-feeding) and reacts to dietary phytase supplementation but not to oral delivery of $m y o$-inositol. Given that $\mathrm{P}$ and $m y o$-inositol are the final end-products of phytic acid hydrolysis, the dynamic appearance of these metabolites in the plasma of pigs (and potentially poultry) may prove useful biomarkers of phytase bioefficacy and other strategies to enhance the degradation of phytic acid in the intestine.

\section{Acknowledgements}

This work was financially supported by DSM Nutritional Products, Kaiseraugst, Switzerland.

A. J. C., O. A., J.-P. R., P. G. and J. W. W. designed the experiment and set the experimental question. F. F. R. conducted the statistical analysis with input from A. J. C.. H. L., O. A. and K. M. A. conducted the animal experimental work. P. G. conducted the laboratory analysis. A. J. C. wrote the first draft of the manuscript to which all other authors then contributed edits and interpretative remarks.

The authors declare that there are no conflicts of interest.

\section{References}

1. Eeckhout W \& De Paepe M (1994) Total phosphorus, phytatephosphorus and phytase activity in plant feedstuffs. Anim Feed Sci Technol 47, 19-29.

2. Maenz DD, Engele-Schaan CM, Newkirk RW, et al. (1999) The effect of minerals and mineral chelators on the formation of phytase-resistant and phytase-susceptible forms of phytic acid in solution and in a slurry of canola meal. Anim Feed Sci Technol 81, 177-192.

3. Cowieson AJ \& Ravindran V (2007) Effect of phytic acid and microbial phytase on the flow and amino acid composition of endogenous protein at the terminal ileum of growing broiler chickens. Brit J Nutr 98, 745-752.

4. Cowieson AJ, Bedford MR, Selle PH, et al. (2009) Phytate and microbial phytase: implications for endogenous nitrogen losses and nutrient availability. World's Poult Sci J 65 , 401-418.

5. Selle PH \& Ravindran V (2007) Microbial phytase in poultry nutrition. Anim Feed Sci Technol 135, 1-41.

6. Selle PH \& Ravindran V (2008) Phytate-degrading enzymes in pig nutrition. Livestock Sci 113, 99-122.

7. Cowieson AJ, Wilcok P \& Bedford MR (2011) Super-dosing effects of phytase in poultry and other monogastrics. Worlds Poult Sci J 67, 225-236.

8. Selle PH, Cowieson AJ \& Ravindran V (2009) Consequences of calcium interaction with phytate and phytase for poultry and pigs. Livestock Sci 124, 126-141.

9. Selle PH, Cowieson AJ, Cowieson NP, et al. (2012) Proteinphytate interactions in pig and poultry nutrition: a reappraisal. Nut Res Rev 25, 1-17.
10. Cowieson AJ, Acamovic T \& Bedford MR (2004) The effects of phytase and phytic acid on the loss of endogenous amino acids and minerals from broiler chickens. Br Poult Sci $\mathbf{4 5}$, 101-108.

11. Ravindran V, Cowieson AJ \& Selle PH (2008) Influence of electrolyte balance and microbial phytase on growth performance, nutrient utilization and excreta quality of broiler chickens. Poult Sci 87, 677-688.

12. Cowieson AJ, Ruckebusch JP, Knap I, et al. (2016) Phytate-free nutrition: a new paradigm in monogastric animal production. Anim Feed Sci Technol 222, 180-189.

13. Cowieson AJ, Ruckebusch JP, Sorbara JOB, et al. (2017a) A systematic view on the effect of phytase on ileal amino acid digestibility in broilers. Anim Feed Sci Technol 225, 182-194.

14. Cowieson AJ, Ruckebusch JP, Sorbara JOB, et al. (2017b) A systematic view on the effect of microbial phytase on ileal amino acid digestibility in pigs. Anim Feed Sci Technol 231, 138-149.

15. Zyla K, Dulinski R, Pierzchalska M, et al. (2013) Phytases and myo-inositol modulate performance, bone mineralization and alter lipid fractions in the serum of broilers. J Anim Feed Sci 22, 56-62.

16. Cowieson AJ, Ptak A, Mackowiak P, et al. (2013) The effect of microbial phytase and myo-inositol on performance and blood biochemistry of broiler chickens fed wheat/cornbased diets. Poult Sci 92, 2124-2134.

17. Cowieson AJ, Aureli R, Guggenbuhl P, et al. (2014) Possible involvement of myo-inositol in the physiological response of broilers to high doses of microbial phytase. Anim Prod Sci $\mathbf{5 5}$, 710-719.

18. Guggenbuhl P, Perez Calvo E \& Fru F (2016) Effect of a bacterial 6-phytase on plasma myo-inositol concentrations and phosphorus and calcium utilization in swine. J Anim Sci 94, 243-245.

19. Walk CL, Santos TT \& Bedford MR (2014) Influence of superdoses of a novel microbial phytase on growth performance, tibia ash, and gizzard phytate and inositol in young broilers. Poult Sci 93, 1172-1177.

20. Marchant-Forde JN, Matthews DL, Poletto R, et al. (2012) Plasma cortisol and noradrenalin concentrations in pigs: automated sampling of freely moving pigs housed in the PigTurn versus manually sampled and restrained pigs. Anim Welfare 21, 197-205.

21. Frieler RA, Mitteness DJ, Golovko MY, et al. (2009) Quantitative determination of free glycerol and myo-inositol from plasma and tissue by high-performance liquid chromatography. J Chromatogr B Analyt Technol Biomed Life Sci 877, 3667-3672.

22. Leung KY, Mills K, Burren KA, et al. (2011) Quantitative analysis of myo-inositol in urine, blood and nutritional supplements by high-performance liquid chromatography tandem mass spectrometry. J Chromatogr B Analyt Technol Biomed Life Sci 879, 2759-2763.

23. Clements RS Jr \& Diethelm AG (1979) The metabolism of myo-inositol by the human kidney. J Lab Clin Med $\mathbf{9 3}$, 210-219.

24. Groenen PM, Merkus HM, Sweep FC, et al. (2003) Kinetics of myo-inositol loading in women of reproductive age. Ann Clin Biochem 40, 79-85.

25. Dang NT, Mukai R, Yoshida K-I, et al. (2010) D-pinitol and myo-inositol stimulate translocation of glucose transporter 4 in skeletal muscle of C57BL/6 mice. Biosci Biotech Biochem 74, 1062-1067. 
26. Yamashita Y, Yamaoka M, Hasunuma T, et al. (2013) Detection of orally administered inositol stereoisomers in mouse blood plasma and their effects on translocation of glucose transporter 4 in skeletal muscle cells. J Agri Food Chem 61, 4850-4854.

27. Schmeisser J, Seon A, Aureli R, et al. (2017) Exploratory transcriptomic analysis of gene expression patterns in muscle tissue of broilers fed a phytase supplemented diet. I Anim Physiol Anim Nutr 100, 563-575.

28. Proszkowiec-Weglarz M \& Angel R (2013) Calcium and phosphorus metabolism in broilers: effect of homeostatic mechanism on calcium and phosphorus digestibility. J Appl Poult Res 22, 609-627. 